DOI: doi.org/10.21009/IJLECR.042.20

Received: 5 June 2018

Revised: 10 June 2018

Accepted: 14 August 2018

Published: 31 December 2018

\title{
THE IMPORTANCE OF THE IMPLEMENTATION OF DRAMA ANDCULTUREIN SPEAKING CLASS (AN ETHNOGRAPHY STUDY AT STIBA IEC, JAKARTA)
}

\author{
Budiarto $^{1, \mathrm{a})}$ \\ English Literature Department, STIBA IEC, Jakarta. ${ }^{1)}$ \\ budiarto@stibaiec-jakarta.ac.id ${ }^{\text {a) }}$
}

\begin{abstract}
The traditional routines in speaking class are often based on learning materials from a handbook. It is practical because a teacher does not need to think about the syllabus, as it is described clearly in front pages in the book. In addition, by referring to the syllabus in the book, the teacher can easily prepare a lessonplan. When it comes to the implementation of teaching speaking skill, the teacher can just train students based on the topics given with certain grammar points and vocabulary coverage. However, it does not normally give more opportunity for the students to use theauthentic language and culture. Too much guiding students with certain patterns and vocabulary seems to be artificial although vocabulary and grammar are not taught explicitly in a speaking class. Furthermore, without freedom in choosing a topic, students' ideas are too restricted and they tend to memorize language patternsaccording to the topic covered in the book.Nowadays, more and more teachers realize the importance of the implementation of drama and culture in teaching English speaking skill. However, there should be further study to see how a teacher applies drama and culture while teaching speaking skill.

A research conductedat STIBA IEC Jakarta investigated the importance of the implementation of drama and culture in Speaking Class of students from the second semester in 2018.It was intended to see how the phenomena of teaching English speaking skill through drama and culture was implemented. The findings indicated that drama and culture were able to help the students use English more naturally or authentically. The students were able to see whether their English was authentic and culturally acceptable by relating to their experience or knowledge they got from drama. It showed that the more topics in drama the students practiced, the more knowledge about culture they learnt, and the more authentic or natural the language they acquired. Therefore, both teacher and students think that the implementation of drama and culture in teaching speaking skill is important.
\end{abstract}

Keywords: implementation, speaking skill, drama, culture, authentic

Normally, first language speakers use their formal language when they are in the classroom, but when they are outside the classroom, they usually use informal language. They switch from formal to informal language and vice versa, and their language is authentic because they know the culture. As a result, their communication using their first language is natural and socially acceptable. They do not use rigid language language like in the classroom all the time because 
actually there are many different settings and situations in which rigid language like the one in the classroom is not always socially appropriate.

In contrast, in a foreign language class, the use of English is less than one and a half hours per meeting. In general, they use English based on certain language patterns and vocabulary according to the topics discussed from a handbook. When the students are outside the classroom, they do not often communicate with their friends in English. They may try to learn English outside the classroom, but they meet the language that looks different from the language they learn in the classroom. Film is one example that contains not only authentic language but also culture. The students cannot comprehend the English film well because the language is not as well structured as the one learnt in the classroom. Another example is English drama, which contains language that is not as well structured as a story from a textbook, but it actually can be taught to students who want to be able to speak English more naturally.

Students have to learn about culture from authentic resources such as drama if they want to speak English more naturally. On the other hand, if students stick to the traditional learning, they will just learn the language that is too artificial. Students construct sentences based on certain patterns and vocabulary lists. They may speak fluently in the classroom, but they have to face the real world outside the classroom. When it comes to the use of the real language which contains culture, the language they have learnt are often not be effective in the real communication. It is the teacher's responsibility to make learning English more natural by focusing more on the conversation based on authentic materials that contains understanding about culture rather than focusing on well structure language based on a classroom handbook (Holmes, 2007: 425).

According to Peterson and Coltrane, there are many words and sentence patterns in drama that are not the same as the ones used in a handbook. In addition, the more topics covered in drama, the more knowledge about culture the students get. Drama can be adapted by the students so that they can perform the drama well. Students may make drama shorter and simpler, but they have to read the whole story before adapting the story (Peterson and Coltrane, 2003: 1).

Introducing culture when teaching a target language requires a long process in order to make learning a language more effective. Students may have different attitudes when learning language containing elements about culture, but most students have positive attitudes towards learning a language when culture is involved. Introducing culture to language learners is important because it can improve communication skill, it can encourage teachers to prepare authentic materials, it can motivate students to learn a foreign language effectively, and it can give students basic knowledge to develop their relationship with international communities (Mohammadi, dan Basirizadeh, 2012: $523)$.

Byram in Sun (2013) states that learning a foreign language and culture encourages students to interact in the classroom according to real social context. Students need such social context, which can be seen when they practice foreign language through drama (Sun, 2013: 372).

Research by Widyahening, et.al. (2013: 119-120) is about the importance of developing materials from drama, how socio-drama is implemented, and how socio-drama effectively improves students' language performance. The research was conducted in six different private universities in central Java. All the students involved in the research are from English Language Department. Students are taught about drama theories and how drama should be performed. When learning socio-drama, students need to know useful language expressions in socio-drama, comprehend the plot, and perform in the socio-drama based on their own characters. Students need to practice performing socio-drama intensively so that their English improves significantly. It is interesting to note that in this research, teaching speaking skill through socio-drama is without a text book at all for the whole one semester, and teachers have to find the materials themselves and adapt the materials according to the students' need (Widyahening, et.al., 2013: 119-120) 
Simpsi says that there could be students from so many different culture backgrounds in one classroom, but it does not mean that students should lose their own culture identities when learning a new culture. In fact, learning a new culture can make students more tolerant with other cultures without ignoring their own culture. That is why they can use English when talking about their culture background or social conditions in their neighborhood. They may find differences between the culture of the target language and the culture in students' first language. By understanding the differences, students will have positive attitudes toward the language they learn and appreciate the uniqueness of the culture from their first language (Simpsi, 2013: 261).

Teaching drama can help students to get new experience from new stories while at the same time they are practicing the target language without ignoring the culture. Getting the experience and knowledge about culture while learning the language makes the learning environment is fun (Medina and Campano (2006: 341)

Research at STIBA IEC Jakarta focuses on both teacher's and students' attitudes toward the implementation of drama in English Speaking Class. It investigates how authentic materials from drama encourage students to practice speaking English enthusiastically. Students had to understand culture in the drama they performed in the classroom.

\section{METHOD}

The writer investigated the phenomena of how stories were used as authentic resources in teaching speaking through drama was implemented. He also wanted to see students' positive attitudes toward drama and culture, especially when they practiced speaking through drama.

The research uses ethnography method, in which the interaction among students during the implementation of teaching speaking English through drama was observed. The teacher activities in giving students freedom to select drama they liked, and how students integrated the culture into drama performance was observed.

\subsection{Data Collection}

The data collection was obtained through hidden camera in the classroom in order to see the implementation of drama and culture in speaking practices. In addition, the data was also taken from the results of teacher's and students' interview.

\subsection{Data Interpretation}

Analysis of the data is based on teacher's and students' attitudes towards the implementation of drama and culture in English speaking class. The instrument used are interviews to the teacher and students.

\section{RESULTS AND DISCUSSIONS}

After one semester, all the findings about the implementation of drama and culture in the speaking class and the results of teacher's and students' interviews are analyzed and interpreted.

The followings are two tables summarized and adapted from Al-Mahrooqi and Takabow's statements (2013: 316) about the implementation of drama and culture in the speaking class. In the checklists, score 4 indicates completely agree (CA), score 3 indicates agree (A), score 2 indicates does not agree (DA), scores 1 indicates does not agree completely (DAC).

Table 1 contains checklist of 10 question items, the minimum score is 10 and the maximum score is 40 . Score between 36-40 means that the teacher completely implements drama and culture, 31-35 means that the teacher implements drama and culture well, 26-30 means that the teacher implements drama and culture fairly, 21-25 means that the teacher is poor in implementing drama and culture. 
Table 1. The implementation of drama and culture in the speaking class by the teacher

\begin{tabular}{|c|c|c|c|c|}
\hline $\begin{array}{l}\text { Checklists of the implementation of drama and culture in the speaking } \\
\text { class } \\
\text { by the teacher }\end{array}$ & CA & A & DA & $\begin{array}{c}\text { DA } \\
\text { C }\end{array}$ \\
\hline $\begin{array}{l}\text { Teacher gives students opportunity to select drama topics according to } \\
\text { the students' interest }\end{array}$ & & $\mathrm{v}$ & & \\
\hline Teacher gives students enough time to prepare drama & & $\mathrm{V}$ & & \\
\hline $\begin{array}{l}\text { Teacher makes sure that students realize that by selecting topics } \\
\text { relevant to their social life, they will use the language appropriately } \\
\text { when they deal with real communication outside the classroom }\end{array}$ & $\mathrm{v}$ & & & \\
\hline $\begin{array}{l}\text { Teacher gives students opportunity to read the whole original drama } \\
\text { story before simplifying and adapting the drama }\end{array}$ & & $\mathrm{v}$ & & \\
\hline $\begin{array}{l}\text { Teacher guides the students to simplify and adapt the drama story, so } \\
\text { that students can perform the drama confidently }\end{array}$ & & & & $\mathrm{v}$ \\
\hline $\begin{array}{l}\text { Teacher makes sure that students feel the culture elements are } \\
\text { important in students' drama performance }\end{array}$ & & $\mathrm{v}$ & & \\
\hline $\begin{array}{l}\text { Teacher lets students choose the characters they want, but they have to } \\
\text { pay attention to the elements of culture in the story }\end{array}$ & $\mathrm{v}$ & & & \\
\hline $\begin{array}{l}\text { Teacher encourages students to keep some original phrases when they } \\
\text { are very important and cannot be paraphrased }\end{array}$ & $\mathrm{v}$ & & & \\
\hline $\begin{array}{l}\text { Teacher lets students adjust the story according to the students' } \\
\text { creativity, but the plots of the story remain the same }\end{array}$ & & $\mathrm{v}$ & & \\
\hline $\begin{array}{c}\text { After each performance, teacher asks students to see how they } \\
\text { understand the culture and message of the story and its implication in } \\
\text { real life }\end{array}$ & & $\mathrm{v}$ & & \\
\hline
\end{tabular}

Based on table 1 the implementation of drama and culture in the speaking class by the teacher, the total score is 31 , which means that the teacher implements drama and culture well. There are three items that obviously show that the teacher completely implements drama and culture.

First, teacher makes sure that the topics selected by the students can be used outside the classroom in real communication. This makes the language chosen authentic and natural, which helps students to speak naturally too.

Second, by letting students choose the characters they want, teacher makes the students become more motivated because they perform according to their personality and something they like. In addition, teacher makes students pay attention to culture in the story.

Third, teacher encourages students to keep some original phrases when they are very important and cannot be paraphrased. It makes the communication using English sounds natural, because some phrases in drama are untranslatable and the meanings can be weird when paraphrased.

There are 6 items that the teacher agrees about the implementation of drama and culture, but unfortunately, there is one that the teacher does not agree completely. Item number 5 indicates that teacher does not guide the students to simplify and adapt the drama story. Based on the observation, teacher gives students independence to work in group. Teacher just facilitates students to work in groups to simplify and adapt the drama, but the teacher does not specify the procedures or 
techniques of how to simplify or adapt the drama story. However, most students manage to perform drama stories well by working together in their group without teacher's assistance.

Table 2. Students' attitudes toward the implementation of drama and culture in the speaking class

\begin{tabular}{|c|c|c|c|c|}
\hline $\begin{array}{l}\text { Students' attitudes toward the implementation of drama and culture in } \\
\text { the speaking class }\end{array}$ & CA & A & DA & DAC \\
\hline $\begin{array}{l}\text { Students feel they are given opportunity to select drama topics } \\
\text { according to the their interest }\end{array}$ & 4 & 6 & 5 & 0 \\
\hline Students have enough time to prepare drama & 2 & 9 & 3 & 1 \\
\hline $\begin{array}{l}\text { Students are sure that by selecting topics relevant to their social life, } \\
\text { they will use the language appropriately when they deal with real } \\
\text { communication outside the classroom }\end{array}$ & 10 & 3 & 2 & 0 \\
\hline $\begin{array}{l}\text { Students have enough time to read the whole original drama story } \\
\text { before simplifying and adapting the drama }\end{array}$ & 8 & 6 & 0 & 1 \\
\hline $\begin{array}{l}\text { Students are guided to simplify and adapt the drama story, so that they } \\
\text { can perform the drama confidently }\end{array}$ & 0 & 0 & 3 & 12 \\
\hline Students think that the culture elements in the drama are important & 5 & 7 & 2 & 1 \\
\hline $\begin{array}{l}\text { Students have freedom to choose the characters they want, and pay } \\
\text { attention to the elements of culture in the story }\end{array}$ & 9 & 4 & 2 & 0 \\
\hline $\begin{array}{l}\text { Students keep some original phrases that are very important and } \\
\text { cannot be paraphrased }\end{array}$ & 8 & 4 & 2 & 1 \\
\hline $\begin{array}{l}\text { Students adjust the story according to the their creativity, but the plots } \\
\text { of the story remain the same }\end{array}$ & 7 & 7 & 1 & 0 \\
\hline $\begin{array}{l}\text { Students understand the culture and message of the story and its } \\
\text { implication in real life }\end{array}$ & 2 & 9 & 2 & 2 \\
\hline Sub total & 196 & 216 & 46 & 8 \\
\hline
\end{tabular}

Because there are 15 students in the speaking class, the maximum score of students' attitudes toward the implementation of drama and culture in the speaking class is $15 \mathrm{X} 40=600$. Score 451-600 is excellent, 301-450 is good, 151-300 is fair, and 0-150 is poor.

Based on table 2 students' attitudes toward the implementation of drama and culture in the speaking class, the total score is 466 , which means that students' attitudes toward the implementation of drama and culture in the speaking class are excellent. There are four students' responses that shows the teacher completely agree, which indicate more than half of students in the classroom completely agree.

First, 10 Students are sure that by selecting topics relevant to their social life, they will use the language appropriately when they deal with real communication outside the classroom.

Second, 8 students have enough time to read the whole original drama story before simplifying and adapting the drama.

Third, 9 Students have freedom to choose the characters they want, and pay attention to the elements of culture in the story, fourth, 8 Students keep some original phrases that are very important and cannot be paraphrased.

However, there are 12 students who disagree completely being guided to simplify and adapt the drama story. However, based on the observation, most students are enthusiastic, and they want to simplify and adapt the drama story without being guided by the teacher. In general, based on the whole ten items answered, most students have positive attitudes toward the implementation of drama and culture in the speaking class, with total score of 466, which is excellent. 
However, further study is still needed to obtain more findings that can give more confirmation and insights about the research. Further investigation on implementation of drama and culture in the speaking class by the teacher and students' attitudes toward the implementation of drama and culture in the speaking class can have positive impacts in language teaching to get more understanding and knowledge about the phenomena of teaching a foreign language that pays attention to culture through drama.

\section{CONCLUSION}

Drama helps students to speak English more naturally than when they use resources from a handbook. Students can express their thoughts and feelings through drama, so they can practice speaking more fluently, especially when they like the characters they select. In general, teacher can implement well the drama and culture in speaking class, and students are very enthusiastic about the implementation. Speaking English is not just about language patterns and vocabulary covered in a text book. Students need authentic resources such as drama because the language is more realistic and it contains culture that can deliver the message of a drama story more effectively. That is why some dialogs in the drama still keep the original phrases because there are no exact equivalent when the phrases are stated in different ways. This indicates how important learning to speak English by including drama and culture.

In this research, it is true that the teacher does not guide the students to simplify and adapt the drama story, but the teacher can successfully facilitate the students to work on their own in order to be able to simplify and adapt the drama story by themselves. However, students' exposure to drama stories and ample time allocated to students to read and comprehend the whole stories by themselves may help students to simplify and adapt the original stories. It is important to keep drama story short and simple, so that students can perform the drama well.

Further investigation on implementation of drama and culture in the speaking class by the teacher, and students' attitudes toward the implementation of drama and culture in the speaking class can have positive impacts in language teaching to get more understanding and knowledge about the phenomena of teaching a foreign language that pays attention to culture.

\section{REFERENCES}

Al-Mahrooqi, Rahma dan Takabow, L. Mary. (2013). Drama in Oman to Improve English Profeciency Among English-Major College Students. International Journal of Arts and Sciences. p. 316.

Holmes, Janet (2007). An Introduction to Linguistics. London: Roultedge.

Mohammadi, Somayeh Chahak dan Basirizadeh, Fatemeh Sadat. (2012). The Study of

Culture on Foreign Language Teaching. International Journal of Social Science and Humanity. p. 523.

Medina, Carmen dan Campano, Gerald. (2006). Performing Identities through Drama and Theatro Practices in Multilingual Classrooms. Language Arts, 341. Vol. 3. No. 4.

Peterson, Elizabeth dan Coltrane, Bronwyn. Culture in Second Language Teaching. (2003). Eric Clearinghouse on Languages and Linguisticsp. 1.

Simpsi, Aspasia. (2013). Theatre in Education and Heritage Language: The Case of a Greek Community School in London. International Journal of Arts \& Sciences. p. 261

Sun, Li. (2013). Culture Teaching in Foreign Language Teaching School of Foreign Languages, Changchun University of Science and Technology, Changchun, China. Theory and Practice in Language Studies. p. 372.

Widyahening, Tri Evy, et.al. (2013). A Drama Textbook With Sociodrama Method. International Refereed Research Journal. p.119-120, www.researchersworld.com. Vol.-IV, Issue- 4(1) 